\title{
The Legal Historian, Masochist or Missionary? A Canadian's Reflections
}

\author{
JOHN MCLAREN*
}

\begin{abstract}
INTRODUCTION
In this article I address the question of the relevance of the teaching of and research into legal history to the broader mission of legal educators. ${ }^{1}$ Based on my experience in devising and teaching courses in Canadian legal history and close observation of the growth of this area of scholarship in Canada, I argue strongly that legal historical instruction and research is vital to both the intellectual and practical endeavours of law schools. I do so because of a belief that knowledge of the development of law, legal institutions and legal ideology in the context of political, social and economic forces is essential to an understanding of legal culture (especially one's own), and that historical understanding increasingly provides the context in which lawyers are called upon to apply their intellectual talents and skills to live problems.
\end{abstract}

\section{TEACHING IN AND RESEARCH INTO LEGAL HISTORY IN CANADA}

\section{The Growth of the Field: From Famine to Feast}

Prior to 1970 it would have been difficult to claim that there was a definable body of Canadian legal historical scholarship, let alone interest in teaching in the field. ${ }^{2}$ With the exception of Quebec in which there was periodically interest on the part of scholars in tracing aspects of the politico-legal history of the province, ${ }^{3}$ and Ontario in which the iconoclastic efforts of Justice William Renwick Riddell had produced a series of books and 
articles on the institutional legal history of the jurisdiction since $1791,{ }^{4}$ what passed for legal history lay predominantly in the anecdotal and antiquarian panegyrics generated by bench and bar. Legal history was often taught in Canadian law schools as a compulsory course. In the Common Law provinces it was English Legal History, more often than not offered in “A 1066 and All That” format, with a passing nod to the fact of reception of English Law into the wilds of British North America at the very end of the course, if time allowed. ${ }^{5}$

Since 1970 legal history has developed into a vigorous field of Canadian history with increasing linkages and overlap with elements of social, economic and intellectual history. This is the result of the efforts of a group of pioneers from both law schools and history departments to encourage teaching and scholarship. ${ }^{6}$ It also stems from institutional initiatives within both the legal profession and universities to support legal historical writing ${ }^{7}$ and the exchange of research findings and experiments in teaching methodology. ${ }^{8}$ The consequence is that today there is a growing literature of generally high quality which supports Canadian legal history courses in most law schools and at least some history departments. ${ }^{9}$

\section{The Present State of Legal Historical Scholarship in}

\section{Canada: A Plurality of Interests, Theories and Methods}

Based on a sampling of monographs, collections of essays, articles and conference papers on Canadian legal history and the disciplinary backgrounds of those working actively in the field it is evident that scholarship in the area is highly pluralistic in terms of its substance, theoretical context and methodology. Legal history being written in Canada is not confined just to explications of doctrinal and institutional evolution (as much traditional English legal history has been). It extends to investigation of the cultural factors, social forces and values, ideological and intellectual impulses and political and economic realities on the development of law, legal institutions and attitudes towards law. It has attracted researchers whose interests originate in geography, political science, gender studies, linguistics, sociology, anthropology, native 
studies, criminology, history, cultural and ethnic studies and economics. Their intellectual traditions are also diverse conservative, liberal, Marxist and feminist. As a consequence a rich body of theory is being employed in postulating hypotheses and interpreting results, including discursive, critical and structuralist, as well as more traditional, evolutionary and rationalist models. Finally, there is methodological diversity in the work being done. A wide range of documentary, archival and even oral evidence is being interrogated by the use of empirical, statistical, processual, linguistic and literary as well as doctrinal, institutional and biographical analysis. ${ }^{10}$ The broad character of research into Canadian legal history is healthy both because of the range of insights it involves, and because it provides the basis for intellectual engagement on the treatment and interpretation of the historical record. The lively debate which has developed around the question of the character of the politico-legal culture of Upper Canada before William Lyon MacKenzie's rebellion of 1837 is perhaps the most telling example of contention to date. ${ }^{11}$

\section{MODERN LEGAL HISTORY}

\section{Meanings}

It is important to clarify what is meant by teaching and research into modern legal history. The term does not refer to the narrow doctrinal and institutional instruction and research which traditionally constituted legal history in most Common Law jurisdictions in Canada. The latter concentrated almost exclusively on the evolution of the substance and institutions of the Common Law itself - the royal courts, the legal profession and the body of law crafted by the royal judges in the context of the litigation of disputes. ${ }^{12}$ Although the teaching of and research into legal history in the sense in which I use it includes as an important element analysis of the substance, institutions and processes of the law, its broader and dominant focus is what several contemporary legal historians have described as “external legal history”. The exponents of the latter insist on viewing law in its social and intellectual context, employing interdisciplinary insights, especially those from the humanities, and drawing upon the theoretical models and methodologies of the social sciences. ${ }^{13}$ 
This contextual approach to legal history is not the product of academic dyspepsia, but flows from a realization that modern legal culture, while it still owes much to an ancient legal heritage, is more especially a product of the dramatic political, social and economic changes in western societies over the past three centuries. Moreover, while it recognizes that modern law is the product of an impulse towards greater centralization, it also accepts that law and regulation exists in many forms and in many places - that law is in fact fragmented and played out in multiple jurisdictions and forums. Indeed, in an environment in which there are growing challenges to the universality and transcendence of legal systems and norms, as various groups seek to carve out political and legal space for themselves which both reflects and protects their cultural identity, it is likely that we can expect more rather than less legal pluralism. $^{14}$

\section{Modern Legal History and Cultural Relevance}

Citizens of countries in the developed world live and work in complex commercial and industrial societies - the product of an explosion of knowledge associated with an evolving politico-social culture which has placed an enhanced value on individualistic effort, particularly in the application of human ingenuity to wealth generation and to technological innovation and its application. These countries have populations which are increasingly diverse in their ethnic and cultural composition and experience as they have attracted migrants from around the world. The modern state in various guises has come to legislate and regulate extensively economic and social activity, to further individual initiative, but at the same time to temper and control it and to manage the economy and society in the name of a broader collective or "public" interest. Although these countries have experienced an increase in the material quality of life, they are at the same time faced with serious problems of alienation and conflict in human relations, accentuated by the impersonality of modern life, the breakdown of community affinity and the resulting lack of control which individuals feel they have over their lives. Despite attempts to reduce social and economic inequities, differences in wealth and social status remain and constitute a significant irritant. They are thus a continuing challenge to political, social and legal ingenuity. All political 
communities in the world are increasingly subject to the economic and social imperatives of powerful sectional interests over which their governments and citizens have seemingly little control and whose operations and actions are often legitimated by the legal system. Finally, the economic and social future of the developed nations is inextricably tied to the fortunes of people elsewhere in the world, whether by trade, humanitarian concern or environmental realities.

These changes did not occur magically or overnight. They stem from a lengthy process of reorientation in economic and social priorities and ordering which was influenced by changes in political organization, in exploration and trading patterns, in the forms of technology, in the nature of religious belief and in the objectives of philosophical and scientific speculation, as well as by associated demographic shifts. It is naive to suppose that law stood in splendid isolation to these events. It acted as both a conditioner and agent of this process of cultural transformation, and, in turn, was affected by it. In the result it became a much more complex body of knowledge and practices than was true of either ancient or mediaeval law.

\section{The Scope of Modern Legal History}

Law in developed countries is not simply, if it ever was, the distilled wisdom of a small elite reacting in relative isolation and with singular authority to the individual crises in the human condition which present themselves as court cases (which used to be the exclusive focus of English legal historians). It constitutes an array of regimes - legislative, regulatory and bureaucratic, as well as judicial, responding to generic as well as individual problems. It also extends to forms of private ordering, for example the rules, practices and processes of corporations, trading companies, market regulators, professional bodies, trade unions, security agencies and religious sects which enable them to fulfil1 their social, economic or spiritual functions and to govern their members ${ }^{15}$ Western societies are constantly challenged to mediate through law, as well as by other social systems, past experience, present reality and future aspiration. This process does not, of course take place in a vacuum, but in the context of the historical experience of those societies, how their populations and representatives view themselves and their place within the world and what they consider 
as desirable objectives in advancing further material prosperity, the quality of life and human values. Viewed in this light, an appreciation of the history of law as a social phenomenon is a crucial element in understanding the place of law in the broader socio-political culture, the extent to which it reflects particular cultural beliefs and biases, its ideological and intellectual inspirations and imprints, its meaning to those who employ it and who it has affected, its use and manipulation both to establish and resist political, social and economic control by the state and powerful private interests and its efficacy as an instrument for mediating disputes between diverse interests and for working desired social change.

An understanding of the evolution of law and legal culture is also valuable in demonstrating the relative influences of indigenous and received legal ideas. This is a particularly important balance for societies which are the product of a colonial experience. While such speculation may seem more relevant to countries such as India, Japan and Thailand which have experienced the direct or indirect imposition of foreign legal systems upon existing and subsisting traditional law and custom, it is also relevant to former settler colonies, such as Canada, Australia and the United States. In the latter European law has been refracted through lenses coloured by local as well as external political, social and economic conditions. Moreover, in all of these national jurisdictions there is a belated but growing realization of both the pre-existence and durability, against all the apparent odds, of aboriginal law and custom, which requires understanding and respect.

\section{The Cultural Contingency of Legal Experience}

The discerning study of a country's legal history may assist in the recognition of the cultural relativity of the law and its institutions. The realization is an important check against two diseases which afflict some politicians, judges and lawyers, and even academics, namely legal-political "presentism” and cultural snobbery. The first ignores or downgrades the relevance of a country's socio-legal culture in the cause of some apparently more noble vision of international cooperation and integration, or cultural emulation. ${ }^{16}$ Some Canadians would argue, for instance, that the headlong rush into the North American Free Trade Agreement and 
acceptance of its legal mechanisms took place in a political environment in which Canadian cultural identity was sidestepped by politicians woefully ignorant of the country's history. The second malady is that of assuming that the legal development of a settler colony and ultimately independent nation is the glorious and undefiled spread of the colonial power's legal system and tradition of justice. This is typically articulated in rhetorical outbursts about being "heirs to the finest and most civilized system of justice that mankind [sic] has devised". In an educational context it underlies a view which is sadly still not dead - that the former colony lacks a legal history or that it is but a pale reflection of that of the inherited system. It is important in charting the socio-legal history of particular countries that care is taken to highlight the reality and authenticity of their experience, practices and ideas, and to resist the temptation of assuming an undiscriminating and blanket process of the translation of concepts, doctrine, institutions and ideology from the colonial parent to the colonial child. ${ }^{17}$ It also means that the legal historian must be cognizant of the wealth and value of the scholarship of political, social, economic and intellectual historians of the jurisdiction or jurisdictions in which they work, which provides the broader context in which law has evolved and against which its role and impact can be assessed.

\section{The Transference of Legal Institutions and Legal Ideology}

It is of course important at the same time as stressing cultural relativity to recognize and investigate the transference and absorption of external legal culture, both in terms of the value systems which colonizers and settlers brought with them and the ongoing penetration and cross fertilization of legal ideas which have occurred since in former settler societies with western legal systems. ${ }^{18}$ In this sense the teaching of and research into legal history is a comparative project which allows the teacher and scholar to draw on a diverse array of data and literature. Canadian legal historians perhaps come naturally to the comparative aspects of the enterprise, because of the dual European roots of the country's legal system and culture and the socio-economic realities of sharing a common and porous border with the United States. What is often forgotten, however, is that within the British imperial 
system the transference of legal ideology and institutions was not invariably from Britain to the colonies and dominions. There is increasing evidence being unearthed by legal historians of borrowing between the colonies and dominions, assisted by the peregrinations of governors, bureaucrats and judges, immigration and emigration of private individuals and groups and improved modes of communication. There are several examples of relevance to Australia and Canada. The influence on colonial policy and law in the mid-nineteenth century of that involuntary nomad Edward Wakefield Gibbon are well known to historians in Australia, Canada and New Zealand. ${ }^{19}$ The following examples are less well documented. The evolution of an official system for regulating the gold fields of British Columbia to replace the self-governing regimes of miners born of earlier experience in California, was based in large part on Australian models from the 1850s gold rushes. ${ }^{20}$ Similarly, when the North West Territories and British Columbia came to develop a legal framework for the allocation of water resources, Australian and New Zealand administrative schemes were appealed to in both western Canadian jurisdictions. ${ }^{21}$ On a sourer note, research into the inspiration for the anti-Chinese legislation enacted in British Columbia in the 1870s and 1880s and the dominion Chinese Immigration Act of 1885 demonstrates models borrowed from Queensland and New South Wales respectively. ${ }^{22}$ There are examples of the movement of legal ideas in the opposite trans-Pacific direction, one of the most obvious being the transference of doctrine and theory on aboriginal rights.

\section{Legal Culture or Cultures?}

If, as I have suggested, cultural specificity is a desirable objective in researching the legal history of national political communities, it may also be a worthy aim in how the legal history within a nation is viewed. Given the staggered timing and the different political, economic, geographic and social conditions in which European conceptions and institutions of law took root and grew in settler countries such as Canada and Australia, it is impossible to talk of a monolithic legal culture. Naturally, given the similarities in ethnic background of the earliest settlers and the objectives of the colonial project, there was a feeling of cultural identity and roots and transcendent patterns of political-legal 
organization and ideology. However, to suppose that the legal cultures of British Columbia, Nova Scotia and Ontario, or of New South Wales, South Australia and Western Australia were identical, is to ignore the diversity in time, location, demography, theory of plantation and political and social influences to which they were subject. The recognition of this truth should be sufficient guard against being caught in the trap of "legal essentialism or imperialism” (what in the Canadian context Graham Parker has dubbed "Ontariocentrism"), ${ }^{23}$ and to commend the examination of law in the so-called "peripheries" as well as in the metropolitan "cores", in small local communities as well as in provinces or states, territories and cities, and in the context of professional, communal, commercial, trade and religious, as well as official, jurisdictions. The realization of a plurality of legal cultures within a nation also provides opportunities for comparative investigation of legal development.

\section{Reconstituting the History of Legal Institutions and Agents}

It is obviously important to the legal historical project that time and effort be directed to investigation of the status, role and motives of those who create, apply and enforce the law - its institutional and professional cultures. From what I have already said, it should be apparent that the potential ambit of such work is broad, embracing not only the courts, judges and lawyers, but the history of legislation and its promoters and sponsors, of administrative bodies of all sorts, the relationship of courts and legislative bodies and the role and working of private jurisdictions.

Within the traditional ambit of historical interest in the institution of the laws, namely the courts and judges, it is vitally important that these not be viewed as disembodied entities limited in their role to the application of a peculiar brand of logic and syllogism. Rather they are to be seen as living, breathing bodies challenged by and responding to competing pulls of the search for reason, order and consistency, the political and psychological effects of the actual and symbolic power which they exercise, claims that law needs to and is capable of change to reflect altered political, social and economic reality and their own ideological biases and personal views on justice and morals. Our understanding 
of the political and cultural significance of courts and judges has been greatly assisted in recent decades by the work of both social and legal historians. The relationship between the judicial function, political power and authority — and social control has been imaginatively investigated and critiqued by EP Thompson and his proteges, such as Douglas Hay and Peter Linebaugh, ${ }^{24}$ and, from a more agnostic position, by John Beattie and Jim Phillips. ${ }^{25}$ Paul Romney has taken a somewhat different cut by examining the political relationship between the courts, the executive and the legislature in the person of the chief law officer of the Crown in the colonies and dominions, the Attorney General. ${ }^{26}$ The work of Robert Stevens on the House of Lords has demonstrated the connection between political and social belief and judicial philosophy and how it has played out in court decisions. ${ }^{27}$ Contemporary judicial biographers in the United States and Canada are contributing similar insights into the motivations of courts and judges in those countries. ${ }^{28}$ From another vantage point Brian Simpson's engaging studies of celebrated cases proves that the subjects of litigation are not inevitably accidental or the result of whim, but embedded in the broader political, social and economic conditions of the day. ${ }^{29}$ In recent years a number of Canadian legal historians have used case studies to good effect to demonstrate the importance of these connections between law and society. ${ }^{30}$ Much more is promised with the work currently under way on a Canadian State Trials Series. ${ }^{31}$ There is room for expansion of the intellectual framework in which the legal profession is studied. In recent decades in social theory there has developed a strong interest in the connection between ideology and culture and the processes by which knowledge is constructed, diffused and reconstructed. In the hands of Michel Foucault, the leading scholar in the field, the focus has typically been the knowledge of professional elites. ${ }^{32}$ This work is suggestive of lines of fruitful historical research into the legal profession and institutions and the control over knowledge and its use which they have clearly exercised. ${ }^{33}$ It is also helpful to study the ways in which that knowledge has been refracted and reconstituted depending upon the role and position of the actor in the hierarchy. Work which is being done on the history of women lawyers and those from minority ethnic and racial groups in Canada is demonstrating that, while the pull in the profession to conformity 
and acceptance of an elite role has always been strong, the institution is not entirely monolithic. It has contained and suffered, often grudgingly, the mavericks and renegades - those who have seen in the law the basis for attacking the political, social and economic status quo. It has been lawyers from these groups who have often been in the forefront of campaigns for human rights and law reform designed to secure greater social justice and genuine equality. ${ }^{34}$

\section{Social Actors and Legal Culture}

Although an understanding of the socio-political significance of legal decision makers and lawyers is important, one should also be prepared to recognize that knowledge of the law and legal institutions and visions of legality is not confined to the agents of the law. In the words of Wes Pue, "all social actors are producers as well as readers of legal knowledge". 35 Accordingly there is a strong argument for incorporation into study and research into the history of law as a social phenomenon of the cognitive and psychological impact of law on those outside its walls who have used and been affected by it and the extent to which that experience is converted into distinctive thought patterns and discourses about law. In this process particular attention needs to be paid not only to those who have employed law to satisfy their political, social and economic needs, but also to the attitudes of those resisting in one way or another the application of law to them, especially the members of "deviant", outcaste and otherwise marginalized communities. The insights of social and feminist historians as well as the historians of race and ethnicity in Canada are providing inspiration for a growing legal historical literature on both the appropriation of and resistance to law within disadvantaged segments of the population. $^{36}$

\section{Expectations}

Teaching and research in modern legal history benefits from the plurality of disciplinary interests engaged in its pursuit in Canada. There are, however, dangers in scholars from disciplines other than history merely "dabbling” in historical work. Lawyers in particular need to heed this advice. They constantly appeal to "historical" 
evidence to justify the arguments they develop on behalf of the interests they serve. Often what this means in practice is a mechanical and positivistic exercise in which appeal is made to past authority which fits the arguments being made and is appropriately located in the political or legal hierarchy. It belies any concern for the social context of the historical event and any appreciation of the contingency of legal as well as social evolution. Even where lawyers, including some in the groves of academe, endeavour to give work an historical perspective (by no means an undesirable objective) the product is often descriptive and uncritical.

By the same token there are theorists, especially in the social sciences, whose historical insights are suspect because the history they teach or do is subservient to the theory they wish to further. As my colleague Hamar Foster has observed, it is all too easy to select the historical evidence which supports a priori conceptions of social organization and development, and to gloss conveniently over that which stands in the way of theoretical purity.

Legal historical endeavour, whether in research or teaching, must involve or draw upon the product of serious scholarship based on investigation of primary sources.

Understanding clearly the role which empiricism, statistical analysis and theory play in the generation of legal history has been assisted in Canada by the interaction of people, from different disciplines who research in the field and cognate areas. In many instances this is informal through encounters at conferences and symposia. In others it is much more formal, such as the establishment of cross appointments between history departments and law schools, and the collaboration of research teams drawn from different disciplines.

\section{The Practical Uses of an Knowledge of Modern Legal History}

The relevance of legal history is not confined to the intellectual satisfaction to be derived from understanding the legal culture in which one works and has one's being. It has in certain circumstances a practical value to it. Indeed one might argue that the mere fact that a lawyer has an understanding of the history of the law, legal institutions and legal ideology, along with an 
appreciation of the relevance of both legal theory and ethics in the broad sense is likely to produce a more reflective, intelligent and less dogmatic approach to what she or he does in legal practice.

A knowledge of legal history has value at a practical level in two more specific contexts. In the first place the exercise of law reform is one which would benefit in many instances from a sensitive reading of legal history. It is difficult to imagine, for example, that the worthy, although to date intractable, task of reforming and rewriting the Canadian Criminal Code, can be done effectively without a keen appreciation not only of its legislative history, but also of the forces and influences which shaped the original Code passed in 1892 and the frequent and ill-assorted amendments to it. ${ }^{37}$

If for no other reason, what history tells us about the contingent nature and ideological quality of law making provides a valuable antidote to the arrogant belief that we are likely to produce a legal regime of innate comprehensibility, completeness, intellectual perfection and practical attractiveness. An historical sense may counsel modesty and thus realism in the claims we make for the law reform process. That knowledge will at the same time provide us with ample evidence of the failure of legislators to recognize the limitations in law in affecting human behaviour, and of their capacity to misread or to overstate the problems which legislation and regulation is supposed to address. It may also persuade us that law making is in many respects a social experiment and that, rather than leaving it to chance and the vagaries of politics as to whether and how the law is amended, provision is made for periodic review in the legislation itself. Knowledge of legal history is not likely to provide any inspirations for law reform (except perhaps in presenting examples of models to avoid). It is, however, valuable in suggesting caution (even a healthy scepticism) about what it is possible to achieve and the need for full and intelligent investigation of interests and options before launching statutory initiatives.

It is becoming increasingly evident that the nature of litigation has changed in Canada in the past twelve years. More clearly than in the past disputes which reach the courts, and for that matter other decision making bodies, are recognized by arbiters as involving broader issues of social and economic policy. This is largely due to 
the politicization of the role of the courts within the new constitutional order established in 1982 by the Charter of Rights and Freedoms. A whole range of substantive issues requiring an assessment of the meaning of entrenched constitutional values and their impact within the Canadian polity and society have challenged the courts - wage and salary restraint, disarmament, freedom of religion, freedom of speech and expression and protection of the press, abortion, freedom of association, the role of labour unions, accessibility to social welfare programs, discrimination on the basis of race, gender, age, sexual preference and disability, aboriginal land claims and hunting and fishing rights, prostitution and pornography, taxation policy, passive euthanasia, economic competition and a flurry of issues surrounding police arrest and custodial practices, to list only a sample. As constitutional challenges they have raised fundamental question about the nature of Canadian society and government. These are matters which cannot be intelligently addressed without an appreciation of the political, social and economic evolution of the country and the relationship of those processes to law and its development. Although a fitful process, as both judges and counsel readjust to this new reality, there is increasing evidence of a striving to acquire a knowledge of the history of the legal system in which they operate, and the evidential significance of the historical record to an understanding of many of the issues raised before the courts. ${ }^{38}$ One example will suffice. In any litigation involving First Nations land claims or hunting and fishing rights, no judge or lawyer who realizes what is at stake in these conflicts would argue that these matters can be understood, let alone resolved, without the benefit of historical, not to mention anthropological and ethnographic, evidence, including that emanating from aboriginal groups themselves.

It is not, however, only in the constitutional cases in which there is a heightened awareness of the value of an historical sense. Even among private law cases, especially those which reach the Supreme Court of Canada, legal historical knowledge may be of value to their argument and resolution, both in explaining the evolution of legal doctrine and pointing to the changing political, social and economic context in which it operates. ${ }^{39}$

This process of the increasing cultural contextualization of 
Canadian litigation has been very clearly affected by the allowance of intervener arguments in both constitutional and nonconstitutional cases. Indeed, it is often in the briefs of groups, such as the Women's Legal Education and Action Fund, the Canadian Civil Liberties Association and the Canadian Mental Health Association, that one finds the keenest appreciation of the theoretical and cultural significance of the issues at stake.

I have developed the sense while in Australia, a sense confirmed by the recent comments of Chief Justice Mason on the role of the High Court within the Australian constitutional and legal system, that similar challenges within the litigation process have developed and are being met in this country as well. ${ }^{40}$

In emphasizing the value of an appreciation of the historical development of the law in the litigation process, it is important not to claim too much for it, and also to point out inherent dangers in its use in an adjudicative forum. As I have already suggested, to the extent that lawyers have used what they understand as historical evidence traditionally, it is has been a record carefully tailored to what they have seen as the demands and challenges of the adversarial system. The use of precedent, its growth and manipulation by the courts is selective and closely related to the legal argument which counsel employ in order to win the case. The court hearing the litigation is usually constrained by the evidence of past legal development adduced by counsel and has to make a choice between competing versions of that story and what it means in the contemporary context. The introduction of historical evidence in the broader sense in which I have used that term is undoubtedly important in laying before a court as much valuable contextual information as possible, on the basis of which it can hopefully render an informed and intelligent decision. Nevertheless, the forum is still one in which lawyers use evidence to take a position and the judge or judges are forced to make choices based on their reading of its relevance and weight. This means that there is a serious danger of historical understanding being fragmented and reinterpreted as it is used to advocate and adopt particular forensic arguments. In the result the expert witness may become little more than the proverbial "hired gun", and the historical record perverted by its reconstitution to satisfy a system in which there is inevitably a winner and loser. ${ }^{41}$ Some historians 
are acutely aware of and react unfavourably to this "judicialization" of history, and resist attempts to draw upon their research and expertize for litigation purposes. For the legal historian the problem also presents a challenge at an educational level. As I have argued, a general appreciation of legal culture is valuable to an understanding of the discipline which lawyers profess and the system in which they practice. Moreover, there are obvious benefits to legal decisions which involve important issues of public policy being rendered in the context of the best available information and data, including the fruits of historical research. However, it is also important that law students (and lawyers, for that matter) understand that there are definite perils in assuming that it is possible or desirable to treat historical evidence as a pawn in the forensic game. An honest attempt to canvas what may well be different interpretations of history is one thing; to assume that one has the corner on the historical "truth" is another.

\section{WHO, WHEN AND WHAT TO TEACH IN MODERN \\ LEGAL HISTORY?}

\section{Conditioning Factors}

Recognition of the value of teaching legal history in a law school does not dictate how it is taught, let alone when and whether it is inflicted upon the collectivity or is left to student option. These are questions on which there will be differences of opinion amongst legal historians, not to mention ones colleagues at large. The answers will depend, moreover, not only upon the likes and dislikes of law teachers, but also upon the availability of resources, the structure and flexibility or otherwise of the curriculum and the unpredictability of student interest and demand. All that is possible in an article of this sort, is to share some thoughts born of experience in the "trenches", and to provide some account of what I do.

\section{Interstitial Approaches}

At the very least there should be a concern among legal educators that an historical context is given to some of the courses taught in law school. I do not mean by this suggestion twenty 
minutes on the forms of actions, on the shift from trespass to negligence or the evolution of valuable consideration - followed by an audible sigh or visible glee that that is over for another year. Legal subjects can be introduced and elaborated in a way which is sensitive not only to doctrinal and institutional development, but also to the political, social and economic forces which have shaped or affected the law, and what that may suggest about the relationship between legal development and those influences in our own era. This is possible and desirable in a wide range of courses, both those like Constitutional Law, Criminal Law, Immigration Law, Environmental Law, Family Law, Human Rights and Industrial Relations Law in which the connection between law and policy seems strongest, and those which have been traditionally viewed as where doctrine is taught and refined, such as Contracts, Torts, Property, Commercial Transactions, Business Associations and Taxation. While it is often subjects in the former group which have attracted the new historical scholarship, the literature is not confined to them. In the case of some of latter group there is good historical work which provides the basis for an understanding of doctrinal and institutional evolution as well as ongoing contextual enrichment. For example, an understanding of the concept of contractual obligation in the Common Law and its peculiar evolution can only be informed, it seems to me, by reference to Patrick Atiyah's work on the history of the influence of political philosophy and social and economic theory on the modern law of contracts. ${ }^{42}$

It is not essential that legal academics in these fields become instant legal historians, although there is always something to be said for stretching one's intellectual horizons. The presence of even one legal historian in a faculty of law can provide the basis for a modest degree of collaborative effort in the classroom, and perhaps more efficiently, consultation on ways and means of using legal historical material and bringing it alive. In my time I have guested in classes in Environmental Law, Human Rights, Criminal Law, and, for purposes of discussing research methodology, Advanced Legal Research and Writing. Moreover, I have been able to contribute to the materials which we at the University of Victoria have developed for our intensive Legal Process program for first year students, and to those which we use in several joint sessions 
on charting the borderland of Torts and Contracts.

\section{Courses in and Audiences for Legal History}

Beyond what might described as the interstitial treatment of legal history, there are very strong arguments for a discrete course or courses in legal history in a law school curriculum. If resources will only allow the luxury of one such course, my preference is for a course which treats the history of the legal system or systems in which the students are and will be operating. In short, I believe that every Canadian law school should at the very least offer a course in Canadian legal history. Beyond that, there are a range of possibilities depending upon the research interests of those ready, willing and able to teach in the general area. Within one or other of the Canadian law schools there are courses (typically seminar courses) in English Legal History, Continental European Legal History, the History of Criminal Law and Justice, the History and Theory of Aboriginal Rights and the History of Women and the Law.

As to the audience, I tend to the view that, if serious efforts are made to give an historical context to some of the basic law school courses, there is no strong argument for requiring all students in law school to take a discrete course in the area. There is, I believe, a case to be made for them taking at least one of a number of courses which are designed to view law contextually and critically, but legal history has no obvious claim to primacy over legal theory, the sociology of law, the law and public policy or law and economics. The advantage of an optional course is that students are to an extent self-selected, either because they have experience in historical research or are otherwise genuinely interested in learning. It is also possible in such a setting to combine both law students and honours or graduate students in history, which produces more complex teaching and learning dynamics and, I believe, a better educational experience for the members of both groups.

\section{Teaching and Evaluation Methodologies}

The likelihood that in a legal history course one will have students with different levels of experience and aptitude raises the issue of how the course is taught and student performance 
evaluated. If I had my druthers I would like to see in my own school an introductory course in Canadian Legal History designed to provide students with a panoramic view of legal development, evaluated by an examination, followed by an advanced seminar in which the emphasis in on more specialized topics, and for which the major requirement is a research paper. As the numbers do not warrant such profligacy, not to mention overall resource constraints (someone has to teach Insurance Law) I have settled for a seminar course. Students are evaluated in two ways. The first is the presentation by each student of examples of published scholarship followed by group discussion. I want the students to put themselves in the shoes of particular legal historians as a means of both understanding their work and its intellectual inspirations and assessing and critiquing it in relation to other interpretations of the historical record. The other and primary assignment is a thirty page research paper on a topic of their choice. This requirement reflects my strong belief that legal history courses should ideally be producing good research, and encouraging students with interest and talent to go further in the field, in graduate work. I require that the paper is based upon an analysis of primary sources, which for purposes of this course includes legislation, case law, administrative regulation, reports of parliamentary bodies and Royal Commissions, the records of private jurisdictions as well as a wide range of communications and correspondence, diaries and private publications contained in archival collections. I have the students consult with me before registering their choice of topic, to discuss whether what they propose is manageable, given readily available sources in British Columbia, and in terms of its substantive scope. In some instances I may make a suggestion of a topic where a student is uncertain, but only after seeking to assess the person's broader interests in law, history or both. Overall in some ten years of teaching in the field of Canadian Legal History the results have been encouraging with at least one of a crop of from six to twelve papers a year being of publishable quality and accepted for publication.

\section{Teaching Materials}

As to the materials used in a course in Canadian Legal History, one has to be both selective and inventive. For reasons having to do 
with the relative infancy of the area of scholarship and the concentration of much of the existing research on opening up the historical record of regions, provinces and local communities, there is no national text or materials book on Canadian legal history. To date there is a series of very good collections of essays, but most of these have either a regional focus, or are confined to more discrete areas of legal development, such as business relations or criminal justice. $^{43}$ For obvious reasons those who teach Canadian legal history will tend to concentrate on the legal history of their region or province. With some exceptions there is a growing body of literature which provides the basis for an in-depth investigation of aspects of legal culture of these geographic areas. Perspectives from particular regions and provinces can also be enriched by the use of comparative material from both within and outside Canada. To the extent that an instructor wishes to stress a more national theme, that can be done, using literature which has grown up around more precise themes, such as criminal justice, policing, aboriginal rights or women and the law. In all of this there are opportunities to bring to bear insights derived from other branches of history. The development of a more national perspective will be given a boost by the pending publication of a series of studies under the title Canada's Legal Heritage. This work will include essays on the legal development of each of the country's regions, as well as on thematic topics viewed from a national perspective. ${ }^{44}$

\section{One Person's Vision}

One of the great delights about teaching legal history, especially in a seminar format, is that it is possible to be selective in the areas to be covered, and to relate the substance of the course to one's own research interests, and to some extent, to those of the students. My own course is organized around issues which demonstrate the influence of political, social and economic forces on the law, its institutions, actors and modes of thinking. Several of the topics represent work done or in progress from my research agenda. I do not guarantee to cover all of the themes in any particular year, which means that we do not necessarily have to rush through the syllabus and have same leeway for accommodating students preferences and having them report on their chosen research topics.

First of all, we examine how the development of law in British 
North America after the American Revolution was affected by political and social culture and competing discourses within them. This is done by looking at the debate over whether Upper Canada was the embodiment of eighteenth century notions of ascendant Whig and Tory constitutionalism, refracted through Loyalist ideology, or a more diverse polity in which those views which were undoubtedly present were challenged by radicalism and protoliberalism with its sources in both dissenting traditions in Britain and republican ideology from the United States. The sometimes rocky process of legal development and the role and views of both the judges and lawyers in that jurisdiction are considered in the light of the various strains of opinion in its political and social culture. ${ }^{45}$

To show that the contours of legal culture in British North American differed in some respects depending upon time and place and colonial priorities, a comparison is made of the evolution of the institutions of the law, especially the courts, and the character of judicial ideology in both Upper Canada (founded in 1791) and British Columbia (established in two stages in 1849 and 1858). ${ }^{46}$ This comparison is valuable in that on the one hand it reveals certain commonalties, such as similarities in court structures, the multifaceted roles of the judiciary in frontier communities, the constraining effects of the arrival of responsible government and a commitment to a notion of "the rule of law", and on the other, differences in attitude, reflecting changes in political philosophies and enthusiasms in the intervening half century. The belief system of John Beverley Robinson, of Loyalist Virginian stock, high Anglican Tory, member of the Family Compact in the 1820s and 1830s, Chief Justice of Upper Canada, 1829 to 1862, translated into a rather different and more static, providential and Blackstonian view of the legal order than that of Matthew Baillie Begbie, English barrister of Liberal laissez faire persuasion, evangelical Anglican, Chief Justice of British Columbia, 1858 to 1894, which accommodated the view that legal doctrine and procedures needed to be moulded to some extent to meet frontier conditions and that the law should be used instrumentally by the courts to further the imperial civilizing mission and to curb the excesses of responsible government. ${ }^{47}$

The legal history of the settler colonies and later dominions 
provides a good opportunity to study how the legal profession fits into the socio-political power structure. The work of a number of legal historians looking at the development of the Bar in Upper Canada, New Brunswick and Nova Scotia, and much later in Manitoba and Alberta, shows the special place of an elite profession in a political system in which a landed aristocracy was an impossibility. It also reveals how in time regional demand and the levelling forces of democracy produced a professional group which encompassed individuals with differing views on the nature of practice and the delivery of legal services. ${ }^{48}$ There is, as well, a developing literature on the "challengers" to and mavericks within the profession who had to fight resistance within it, and chose to take a stand against its closed-shop policies and tendency to support the social and economic status quo. ${ }^{49}$

Until relatively recently the only segment of Canadian policing which has attracted scholarly attention is that national icon, the North West, later the Royal Canadian, Mounted Police ${ }^{50}$ There is, as a result, quite a rich literature which assists one in sorting out fact and myth in the history of the Force. Happily, there is now an expanding interest in investigating other forms of police work in the country. This work extends to the municipal forces which have their inspiration in Sir Robert Peel's reforms in the late 1820s in England and the establishment of borough and county forces in the 1850s, the provincial police forces (which to one degree or another sought to emulate Mountie organization and operating procedures) and the various experiments in secret service policing, including the long defunct Dominion Police. ${ }^{51}$ All of this provides material for an examination of competing police traditions and the political factors which influenced the adoption of one rather than the other, as well as opportunities for reflection upon differing philosophies of police work and how they worked out in practice in different places and over different time spans.

The evolution of the system of criminal justice in Canada more generally is an area of speculation which is supported by a burgeoning literature. Drawing upon the work of both legal and social historians, I seek to encourage the students to view criminal law and its administration in a broader political and societal context. This assists their understanding of considerations of class, gender and race as well as changing conceptions of legal order 
which have both moulded it and affected its application. Work in the field of the history of crime and criminal justice in Britain, the United States and Canada from the pens of legal historians, feminist historians, historians of race and ethnicity and criminologists enables one to highlight competing theories of criminal law and punishment. It is, moreover, possible, using these insights, to reflect upon the extent to which deviancy and therefore criminality are socially constructed and how the statistics for both serious and petty offences, as well as the stories of particular offenders, demonstrate the relative impact of factors of class, race and gender at the level of enforcement practise. ${ }^{52}$

There is both ample room for and a body of scholarly writing by economic and legal historians to support the study of the use of the law to facilitate economic development in Canada. ${ }^{53}$ My interests lie, however, in examining the relationship of law and legal ideology to the darker side of economic growth, in particular environmental abuse and industrial accidents. The availability of the common law historically to deal with localized pollution problems has been well canvassed. ${ }^{54}$ which I have done on the attempts of law makers and courts to control the lumber industry and its profligate and harmful disposal practises indicates that, contrary to popular assumption that legislated environmental law is a product of the 1960s, there is a history of ecological harm and legislative reaction to it which stretches back to the 1820s in the eastern part of the country. ${ }^{55}$ In the context of attempts to counter pollution by mill waste it is possible to trace an evolution in legal strategies from private prosecution, through embryonic forms of administrative regulation employing penal sanctions to the amalgam of administrative, managerial and self-policing systems with which we are familiar today. The record of the lumber industry is also a useful vehicle for showing the tension between economic imperatives and the powerful groups promoting them on the one hand and the public interest in protecting the environment and conservation on the other. The documentary evidence also demonstrates how important it is to the efficacy of the law that politicians, bureaucrats and judges believe in it, and that there are coalitions of effort in the community prepared to press officialdom for remedial legal strategies and their serious application.

The history of the law relating to industrial accidents provides 
an excellent basis for exposing a similar process of institutional experimentation: from the common law hobbled by doctrinal and structural limitations to the earliest halting attempts at factory safety legislation and regulation; thence to the mediation of business and labour interests through the provision of worker's compensation as a form of social insurance in lieu of tort actions; and onto the sophisticated managerial regimes and negative incentive schemes which are in place in some jurisdictions today. The work of both labour and social historians has produced a rich contextual literature which supports examination of the efficacy of various models of the law used to respond to the damage to life and limb done in the cause of industrial expansion. ${ }^{56}$ That scholarship also exposes the political and economic trade offs which were necessary on the part of government, business and labour in achieving improvements in the legal protection afforded to workers. It is as well a useful vehicle for demonstrating at a more general level the hegemonic qualities of law in responding to the tension between the demands of capitalism and basic humanitarian concerns by inducing and institutionalizing compromise. ${ }^{57}$

The legal implications of the migration of racially and ethnically differentiated groups to areas dominated politically and socially by Europeans of British ancestry in the modern era provides another set of challenges and opportunities for the legal historian in both research and teaching. My particular interests lie in investigating and explaining the social and legal fate of both Asian immigrants and religious communalists in Canada. Unhappily the political, social and legal history of British Columbia provides extensive archival and press evidence of the rankest form of both official and unofficial discrimination. ${ }^{58}$ The theme is instructive in at least two ways. In the first place it illustrates how law can be both the facilitator and the opponent of injustice. A good example is the battle between the Legislature of British Columbia intent on excluding further Chinese immigration to the province and making life unbearable for existing residents from China, and the early provincial Supreme Court which went out of its way to protect Chinese residents from differential treatment in taxation and access to business opportunity, because, as the judges asserted, it was plainly discriminatory. ${ }^{59}$ Secondly, it provides a good example of the phenomenon, noted earlier, of the 
borrowing of legal ideas and models within the imperial system. In this case the evidence is clear - the early legislative attempts to discriminate against the Chinese in British Columbia owe something to Queensland models, and the dominion Chinese Immigration Act of 1885 to earlier legislation in New South Wales and Victoria. ${ }^{60}$ When it is also considered that the judges in taking a stand against what they believed to be a mob mentality relied on American decisions in similar cases in California and Oregon, the value of this area for comparative study becomes even more compelling. ${ }^{61}$ Largely through the pioneer efforts of and inspiration

provided by one scholar, Constance Backhouse, there is a burgeoning literature on the history of women and the law in Canada. Drawing upon the work of feminist and social historians, and supported by prodigious research into primary sources, the work of Professor Backhouse and others provides valuable insights into the treatment of women by the law in the context of issues as diverse as marriage and divorce, rape, infanticide, seduction, child custody, labour regulation, matrimonial property, abortion and prostitution. It also extends to the struggles which women had to secure access to the legal profession and the judiciary. Another feature of this work which both I and the students have found especially engaging is the use of the stories of particular women and their experiences within the legal culture as means of opening up a more general examination of the law, its patriarchal biases and resistance to and appropriation of it by women. In the course we use Constance Backhouse's excellent text, Petticoats and Prejudice: Woman and the Law in Nineteenth Century Canada, as the focus for discussion and critique. ${ }^{62}$ The final segment of my course embodies an attempt to use a case study as a means of bringing together some of the themes discussed earlier: to examine how ideologies and discourses both inside and outside the law have affected how a particular social practise is characterized for legal purposes, how the law appropriates the practise and how its construction as a "legal" matter or problem plays out in reality as the level of law enforcement and application. The example I use is prostitution which represents on ongoing focus of my legal historical research. This social practise has spawned a rich interpretative literature by social, feminist, and legal historians. ${ }^{63}$ Moreover, the story of its appropriation by the law, the 
development of legal models for dealing with it and enforcement patterns are discernible through a rich vein of written and printed material: governmental documents, the proceedings of moral reform, religious and professional organizations and police and court records. As prostitution was characterized progressively during the late nineteenth and early twentieth centuries as transnational in scope and believed to require international strategies to deal with it effectively there is room for comparative and international institutional analysis as well. ${ }^{64}$

\section{SPREADING THE WORD INSIDE AND OUTSIDE THE}

\section{ACADEMY}

The role of the legal historian is not limited to teaching and researching merely to enrich legal education. If, as I have suggested, there is inherent value in knowledge of legal culture and its connection with political, social and economic forces and theory, the benefits of research should be extended to those working in other disciplines, to the legal profession and to the community at large.

\section{Legal History for Historians}

A number of history departments in Canada now offer courses in legal history - a recognition that this area of social ordering is worth study in its own right and important to a fuller understanding of political, social and economic development. Just as it is important for some legal academics and students to understand history, its materials, theories and methodologies, so is it for some historians, especially those who investigate government and modes of social and economic ordering, to know something of law as an academic and practical discipline. Furthermore, the existence of such courses is valuable in creating an interest among honours and graduate students in the field which is then translated into specific research endeavour in legal history. Despite these positive signs, legal history teaching in history departments is still the exception rather than the rule. Clearly more encouragement needs to be given by historians to the teaching and study of legal history in their midst. While perhaps not going as far as a Canadian historian of the law who has recently argued ruefully that the historians are in 
danger of losing out to the academic lawyers in "capturing" legal history, it is too often the case that the field is treated as a frill in the corridors of history departments. ${ }^{65}$

\section{Support for Teaching and Research}

The teaching of legal history by both legal academics, historians and those in other disciplines is at its best a demanding exercise. There is benefit to both novices and more seasoned scholars interacting with each other on a regular basis. This happens regularly now in Canada in the context of conferences at which papers are given and research and teaching experiences shared. A particularly imaginative experiment which is, alas, no longer in operation, was the annual Legal History Teaching Seminar sponsored by the University of Western Ontario, and directed by Professor David Flaherty during the early to mid-1980s. For a week each summer those interested in teaching and researching legal history came together to listen to and observe the experiences and methods of several established scholars in the field from Canada, Britain and the United States, and to discuss more generally their work and aspirations. In my own case I found that the seminar provided both inspiration and focus, and, above all, the strong feeling that if I got serious about legal history I would not be taking the vows of academic poverty and leading a lonely, monastic life within the larger academy. It was also apparent to me that in addition to being a serious intellectual enterprise legal history could be taught in a lively and engaging fashion. For any group of scholars wishing to spread the word about legal history, this model of the teaching seminar is worthy of emulation. Legal historical research by its very nature takes time and effort and often requires travel to distant sources of material and information. The availability of research funding is important to the enterprise, as is assistance with publication of the product. Happily in Canada both research funds and encouragement in publication have been available not only through the regular channels for social science and humanities research but through those of several bodies set up specifically to support legal historical research and writing. The Osgoode Society, a combined initiative of judges, members of the Ontario Bar and academics was the first into the field in the late 1970s. It has provided subventions to researchers and graduate 
students in aid of work in progress. To date the Society has published in conjunction with various university and commercial presses more than twenty collections of essays and monographs most of a very high quality. More recently, the Supreme Court of Canada Historical Society and the Canadian Legal History Project at the University of Manitoba have been established with similar purposes in mind and both are providing research subventions and organizing the publication of sponsored research.

Research in legal history is problematic, where the sources are disorganized or uncatalogued. Happily in Canada it is increasingly true that through the combined efforts of legal historians and archivists with interests in the field, first rate work has been and is being done on the rationalizing and improving the accessibility of relevant archival material. ${ }^{66}$ Legal historians are also applying themselves to the task of generating both general and area bibliographies to aid research and teaching. ${ }^{67}$

\section{Legal History for the Community}

Most Canadians, including those who claim to be well educated, are woefully ignorant of their country's legal history. Traditionally, with the exception of constitutional history, there were no attempts to treat the development of the law and legal institutions in the educational system. Even today, when there are courses in law at the high school level, these are optional and all to often limited to commercial transactions, or potpourris of topics with little in the way of institutional, conceptual or historical ordering. There is a challenge to legal historians in all of this, in encouraging those who shape and devise curricula in the school system to pay greater attention to the development of legal culture in secondary education, and to ways and means of bringing it alive. $^{68}$

There are simpler ways, however, of generating interest among the general public in legal history. In Canada, as in Australia, there are institutions of the law - courts, legislatures, penitentiaries (either still in use or preserved as heritage centres) which each tell a story about law, its growth and operation. There is every reason why these stories should be disseminated, not simply in written form, but in displays of the artifacts of law, in videos and films, in lectures and in simulations of historic events. Legal historians can 
be helpful not only in pressing for the preservation of historic law buildings, but also in suggesting creative ways in which such facilities can be used to explain the role of law, its institutions and ideas within the community. It is legal historians, together with judges and lawyers, who have been instrumental in forming in both the United States and Canada bodies dedicated to preserving legal heritage sites, launching oral history projects and encouraging research and scholarship. I have already mentioned the Osgoode Society and the Supreme Court of Canada Historical Society and their missions. Another impressive example is provided by the Ninth Judicial Circuit Historical Society in the western United States. Based in Pasadena, California with a fulltime executive director, the Society publishes a quarterly journal, Western Legal History, designed for both the academic and general reader, as well as books of essays and monographs. It supports a vigorous oral history project and has devised a portable display of the history of the circuit which extends back to the 1850s. The Society is also active in the campaign to preserve legal records, not least those of private law firms.

There is no reason why this approach to historical reconstruction should be limited to the "high institutions" of the law, such as Parliament, provincial or state legislatures, the Supreme Court of Canada or the High Court of Australia. Institutions at a regional or local level in some ways provide more accessible facilities for the general public. One example in Canada which is worthy of note is the restored Essex County Court House in Windsor, Ontario which dates from the mid-nineteenth century. It houses a museum of the legal history of south western Ontario and the Detroit frontier. The latter dates back to the seventeenth century when fur traders and settlers from New France established themselves in the area. A restored court room is also available for tours, and is the site of a periodic simulation of the trial of Colonel John Prince of the Essex County Militia for summarily executing several rebels in the abortive Battle of Windsor of $1838 .{ }^{69}$ In Australia the interpretive programs developed in heritage penal, charity and police institutions, such as those at Port Arthur, the Hobart Jail, the Old Melbourne Prison, the Old Beechworth Courthouse, the Justice and Police Museum and the Old Barracks in Sydney and the Migration Museum in Adelaide are similarly 
impressive in the information and sense of drama which they provide. $^{70}$ All these displays and presentations add an important dimension to local communities' understanding of themselves and their past.

\section{CONCLUSION}

It should be now evident where the author fits in terms of the question posed in the title to this article and the latter's implicit message. Australia shares with Canada a legal culture which reflects the fitful but inexorable evolution from colonial status to full nationhood, in a world of dramatic political, social, economic, scientific and technological change. That legal culture, while inspired and coloured by that of the colonizing power, is also an authentic expression of the attempts of successive generations of Australians to mold law and the legal system to the demands and needs of a society and communities faced with political, social and economic challenges which were not a carbon copy of those in Britain. Australian legal historians, like their Canadian counterparts, have taken and are taking up the challenge of exploring and recording the evolution of law, legal institutions and legal ideology in their own country. The product is both profound and engaging scholarship. The work of Alex Castles, David Neal and Bruce Kercher is particularly impressive in this regard. ${ }^{71}$ The struggle which those scholars share with their counterparts in Canada is to persuade their institutions and colleagues of the need to use that knowledge to inform and enrich the broader context and content of legal education. It should also be apparent that, given many similarities in the development of legal culture in what were settler societies, legal historians from Australia and Canada have common ground to till and much to learn from each other.

1 This article started life as a consultation paper to a Canadian Social Sciences and Humanities Research Council examination of funding for law and society research in 1990. In doing that paper I consulted several other Canadian legal historians, whose views are incorporated in the text and recognized in footnotes. I am indebted to David Bell (University of New Brunswick), Wes Pue (then of Carleton University, now of the U of British Columbia) and Hamar Foster, my colleague at the University of Victoria, for their sage comments and insights. The piece was completed while the author was a Visiting Fellow in the Law Program, Research School of Social Sciences, Australian National University, February 1 to April 30,1994. My thanks are due to Bruce Kercher (Macquarie University) and Stephan Petrow (University of Tasmania) for their encouragement in this project. 
2 In the early 1970s this was a cause for both frustration and hope among the small band of teachers and scholars working the field. See G Parker, The Masochism of the Legal Historian (1974)24 U of Toronto LJ 279; R Risk, A Prospectus for Canadian Legal History (1973) I Dalhousie LJ 227; To Know Ourselves: The Report of the Commission on Canadian Studies (Ottawa: Association of Universities and Colleges of Canada, 1975) at 214. The fatter report was highly critical of the failure of Canadian legal academics to investigate the country's legal history.

See A Morel, Canadian Legal History — Retrospect and Prospect (1983) 21 Osgoode Hall LJ 159.

4 See HB Neary, William Renwick Riddell: Judge, Ontario Publicist and Man of Letters (1977) 11 Law Soc of Upper Canada Gazette 144, at 167-171. Riddell served as a trial judge from 1906 to 1926 and then on the Court of Appeal of Ontario until his death in 1945.

5 For a rare example of an attempt to open up the history of English Law in its new colonial habitat, see DC Williams, The Dawn of Law on the Prairies (1962) 27 Sask B Rev 1,26; (1963)28 Sask B Rev 17,63; Law and Institutions in the North West Territories (1869-1905) (1963) 28 Sask B Rev 109; (1964)29 Sask B Rev 51, at 83; (1965)30 Sask B Rev 51; (1966)31 Sask B Rev 1, at 137; (1968)33 Sask B Rev 145.

6 Among those pioneers are Dick Risk (Law, Toronto); Graham Parker and Douglas Hay (Law/History, York); Andre Morel (Law, Montreal); Connie Backhouse (Law, Western Ontario); David Bell (Law/History, New Brunswick); Andre Lachance (History, Universite de Sherbrooke); Louis Knafla (History, Calgary); Blaine Baker (Law, McGill); David Flaherty (History, Western Ontario); Phi1 Girard (Law, Dalhousie); Rod Macleod (History, Alberta); Jean-Marie Fecteau (History, UQAM); Hamar Foster (Law, Victoria).

7 The major initiative from inside the legal profession has been the founding of the Osgoode Society in Ontario which has sponsored at least one monograph or collection of essays every year since 1980, as well as establishing an oral history project and granting fellowships in aid of research. More recently several provincial law societies have instituted archival programs designed to preserve legal records and artifacts. At the level of specific courts, the Supreme Court of Canada Historical Society was formed in 1988. It, like the Osgoode Society, has a publication program.

8 Encouragement has been given to research in Canadian legal history by the establishment of the Canadian Law and Society Association in 1986, and by the initiative of a number of Universities in holding conferences and symposia on legal history. They include the University of Calgary, Carleton University, the University of Manitoba, the University of New Brunswick and the University of Victoria. The University of Western Ontario deserves special mention for having sponsored a series of annual Legal History Workshops in the 1980s under the vigorous directorship of Professor David Flaherty at which the teaching of legal history was the focus of demonstration and discussion.

9 Among the works which have both inspired teachers and scholars and been suggestive in pointing to areas deserving of investigation have been D Flaherty ed, Essays in the History of Canadian Law, Vol I and II (Toronto: Osgoode Society, 1981, 1983); L Knafla ed, Law and Justice in a New Land: Essays in Western Canadian Legal History (Calgary: Carswell Co, 1984); W Pue \& B Wright eds, Canadian Perspectives on Law and Soc: Issues in Legal History (Ottawa: Carleton University Press, 1988); P Girard \& J Phillips, Essays in the History of Canadian Law, Vol III, Nova Scotia (Toronto: Osgoode Society, 1991); C Wilton, Essays in Canadian Legal History, Vol IV, Lawyers and Business in Canada, 1830-1930 (Toronto: Osgoode Society, 1990); R Macleod, Lawful Authority: Readings on the History of Criminal Justice in Canada (Toronto: Copp Clark Pitman, 1988); C Backhouse, Petticoats and Prejudice: Women and the Law in Nineteenth Century Canada (Toronto: Osgoode Society, 
1992); H Foster, J McLaren, \& C Orloff eds, Law for the Elephant, Law for the Beaver: Essays in Transboundary Legal History (Pasadena and Regina: Ninth Judicial Circuit Historical Society and Canadian Centre for Plains Research, 1992); T Loo \& L McLean, Historical Perspectives on Law and Society in Canada (Toronto: Copp Clark Longman, 1994).

10 See W Pue \& B Wright ed, Canadian Perspectives, id, for an illustration of the diversity mentioned in the text. One social historian has criticized the tendency of Canadian legal historians to ignore the central question of class relations in their work, as well as the need to place law in its economic and social context — see B Young, Law ‘in the round' (1986-87)16 Acadiensis 155. I would argue that some of the work published in the past six years, has taken the edge off that criticism.

11 The competing views are that Upper Canada was a domain where Toryism (represented by the Governors and the Loyalist local elite) held sway in the context of a "Georgian constitution"; the countervail is that politics and law were contested from the earliest days of the colony, and that ranged against the Tories both inside and outside the Legislative Assembly were radicals and moderate reformers with their own visions of government and law, some of which were in time 5 be absorbed into mainstream politico-legal thought and action in the colony. See for the former position, see eg B.Baker, 'So Elegant a Web Providential Order and the Rule of Secular Law in Early Nineteenth Century Upper Canada (1988)38 U of Toronto LJ 186; D Howes, Property, God and Nature in the Thought of John Beverley Robinson (1985)30 McGill LJ 364. For the latter, see eg P Romney, Very Late Loyalist Fantasies: Nostalgic Tory History and the Rule of Law in Upper Canada in W Pue \& B Wright ed, Canadian Perspectives, supra note 9 at 119; R Fraser, 'All the Privileges Which Englishmen Possess': Order, Rights and Constitutionalism in Early Nineteenth Century Upper Canada in R Fraser ed, Provincial Justice: Upper Canadian Legal Portraits (Toronto: Osgoode Society, 1992) xxi.

It is interesting to note in this regard that at Cambridge University, a recognized centre of teaching and research into English legal history, prior to the appointment of the present incumbent of the Chair of English Legal History, William Cornish, no legal history course investigated the evolution of English law beyond the early eighteenth century.

The seminal article is R Gordon, Historicism in Legal Scholarship (1980-81) 90 Yale $L J$. The dichotomy between internal and external legal history is explored in D Flaherty, Writing Canadian Legal History: An Introduction in D Flaherty, ed, Essays, Vol I, supra note 9 at 12-19.

14 The pressure mentioned in the text is coming both from countries which have suffered the imposition of western concepts of law upon traditional law and custom (see A Petchsiri, Eastern Importation of Western Criminal Law (Littleton, Colo: Fred Rothman Co, 1987) and from groups within countries, both indigenous and immigrant, which have subscribed or do subscribe to their own legal culture. Examples of the latter are the struggle by First Nations groups in Canada for self-determination, including control over the administration of justice in accordance with their own traditions, and the claims of segments of the Moslem population of Great Britain to recognition of Islamic law and custom as operative in their lives.

15 The historical pluralism of law and legal institutions, even in a supposedly centralized system of justice, such as that in England, is investigated in $\mathrm{H}$ Arthurs, 'Without the Law': Administrative Justice and Legal Pluralism in Nineteenth Century England (Toronto: University of Toronto Press, 1985).

I am grateful to David Bell of the Faculty of Law, the University of New Brunswick for this observation.

17 Among fine Australian examples of legal historical scholarship which fully recognize this reality, are A Castles, Australian Legal History (Sydney: Law Book Co. of Australia, 1982); P Finn, Law and Government in Colonial 
Australia, (Melbourne: Oxford University Press, 1987); D Neal, The Rule of Law in a Penal Colony: Law and Power in Early New South Wales (Cambridge: Cambridge University Press, 1991).

18 Among pioneer studies of the of the spread of legal culture and ideology in settler societies are the following excellent monographs: JP Reid, Law for the Elephant: Property and Social Behaviour on the Overland Trail (San Marino, Calif.: Huntington Library Press, 1986); D Langum, Law and Community on the Mexican Californian Frontier: Anglo- American Expatriates and the Clash of Legal Traditions 1821-1846 (Norman: University of Oklahoma Press, 1987). See also G Marquis, Doing Justice to 'British Justice': Law, Ideology and Canadian Historiography in Pue \& Wright eds, Canadian Perspectives, supra note 9 at 43.

See J Manning Ward, Colonial Self-Government: The British Experience 17591856 (Toronto: University of Toronto Press, 1976) at 207-246.

20 See DR Williams, The Administration of Criminal and Civil Justice. in the Mining Camps and Frontier Communities of British Columbia, in L Knafla ed, Law and Justice in a New Land, supra note 9 at 216; B Gough, Keeping British Columbia British: The Law and Order Question on the Gold Mining Frontier, (1975) 38 Huntington Library Quarterly 269.

21 See D Percy, Water Law of the Canadian West, in McLaren, Foster \& Orloff eds, Law for the Elephant, supra note 9 at 274.

22 See J McLaren, The Burdens of Empire: The Institutionalization of White Supremacy in British Columbia, 1860-1910 in W Gordon \& T Fergus eds, Legal History in the Making (London: Hambledon Press, 1991) 187.

G Parker, Canadian Legal Culture in Knafla ed, Law and Justice in a New Land, supra note 9 at 28-29.

24 EP Thompson, Whigs and Hunters: the Origins of the Black Acts (Harmondsworth: Penguin Books, 1982); The Making of the English Working Class (Harmondsworth: Penguin Books, 1980); Customs in Common (London: Merlin Press, 1991);D Hay, P Liebaugh et al, Albion's Fatal Tree (Harmondsworth: Penguin Books, 1978); P Liebaugh, London Hanged: Crime and Civil Society in the Eighteenth Century (Harmondsworth. Penguin Books, 1991).

J Beattie, Crime and Criminal Justice in England, 1660-1800 (Princeton: Princeton University Press, 1986); J Phillips, The Operation of the Royal Pardon in Nova Scotia, 1749-1815, (1992) 42 U of Toronto LJ 401.

P Romney, Mr. Attorney: The Attorney General for Ontario in Court, Cabinet and Legislature, 1791-1899 (Toronto: Osgoode Society, 1986).

27 R Stevens, The House of Lords as a Judicial Body (Durham, NC: University of North Carolina Press, 1979).

28 Examples of recent judicial biographies in the United States are: C Fritz, Federal Justice in California: The Court of Ogden Hoffman 1851-1891 (Lincoln, Nebraska: University of Nebraska Press, 1991); GE White, Justice Holmes: Law and the Inner Self (New York: Oxford University Press, 1993) and in Canada, D Williams, ... The Man for a New County Sir Matthew Baillie Begbie (Sidney, B.C.: Grays Publishing, 1977) and Duff, A Life in the Law (Vancouver: U of British Columbia Press, 1984); P Brode, Sir John Beverley Robinson: Bone and Sinew of the Compact (Toronto: Osgoode Society, 1984); R Risk, Sir William Meredith CJO: The Search for Authority (1982-83) 7 Dalhousie LJ 713; G Homel, Denison's Law: Criminal Justice and Police Court in Toronto, 1877-1921 (1981)73 Ontario Hist 171; T Thomer \& N Watson, Keeper of the King's Peace: Colonel GE Sanders and the Calgary Police Magistrate's Court (1984)12 Urb Hist Rev 44; J McLaren, Maternal Feminism in Action - Emily Murphy, Police Magistrate (1988) 8 Windsor Yearbook of Access to Justice 234; D Chunn, Maternal Feminism, Legal Professionalism and Political Pragmatism: the Rise of Fall of Magistrate Margaret Patterson, 1922- 
1934 in Pue \& Wright eds, Canadian Perspectives, 91.

AWB Simpson, Cannibalism and the Common Law (Chicago: University of Chicago Press, 1984); Legal Liability for Bursting Reservoirs: the Historical Context of Rylands v Fletcher (1984) $13 \mathrm{~J}$ of Legal St 209; Quackery and Contract Law: The Case of the Carbolic Smoke Ball (1985) $14 \mathrm{~J}$ of Legal St 345; Detention Without Trial in the Second World War: Comparing the British and American Experiences (1988)16 Fla St U Law Rev 225.

30 M Friedland, The Case of Valentine Shortis: A True Story of Crime and Politics in Canada (Toronto: University of Toronto Press, 1986); R Sharpe, The Last Day, the Last Hour, The Currie Libel Trial (Toronto: Osgoode Society, 1988); P Brode, The Odyssey of John Anderson (Toronto: Osgoode Society, 1989); H Foster, The Kamloops Outlaws and the Commissions of Assize in Nineteenth Century British Columbia in D Flaherty ed, Essays, Vol 11, supra note 9 at 308.

This is the joint effort of Barry Wright of the Carleton University Department of Legal Studies and Murray Greenwood of White Rock, British Columbia. For a foretaste of what we may expect, see M Greenwood, Legacies of Fear, Law and Politics in Quebec in the Era of the French Revolution (Toronto: Osgoode Society, 1993).

32 See eg M Foucault, The Birth of the Clinic: An Archaeology of Medical Perception (New York: Vintage Books, 1975); Discipline and Punish: The Birth of the Prison (New York: Vintage Press, 1979); The History of Sexuality, Volume I: An Introduction (New York: Vintage Press, 1980).

33 For recent Canadian studies of the legal profession as a social meritocracy, the elite purveyors of specialized knowledge and the custodians of access and educational standards, see B Baker, Legal Education in Upper Canada 17851889: The Law Society as Educator, in D Flaherty ed, Essays, Vol II, supra note 9, 49; The Reconstitution of Upper Canadian Legal Thought in the LateVictorian Empire (1985) 3 Law and Hist Rev 219; P Sibenik, The Doorkeepers: Legal Education in the Territories and Alberta, 1885-1928 (1990) 13 Dalhousie LJ 419; The 'Black Sheep': The Disciplining of Territorial and Alberta Lawyers, 1885-1928 (1988) 3 Canadian J of Law and Soc'y 109; I Kyer \& J Bickenbach, The Fiercest Debate: Cecil A Wright, the Benchers and Legal Education in Ontario 1923-1957 (Toronto: Osgoode Society, 1988); W Pue, Becoming 'Ethical': Lawyers' Professional Ethics in Early Twentieth Century Canada in D Gibson \& W Pue eds, Glimpses, 237; Common Law Education in Canada's Age of Soap, Light and Water, University of Manitoba Canadian Legal History Project, Working Paper Series (CLHP-WPS-93-1).

34 Examples would include Jacob Cohen who represented members of the Canadian Communist party in from the late 1920s to the 1940s, and Jehovah's Witnesses in the early 1940s. (See W Kaplan, The State and Salvation: The Jehovah's Witnesses and their Fight for Civil Rights (Toronto: University of Toronto Press, 1989); L Betcherman, The Little Band: The Clash between the Communists and Canadian Establishment 1928-1932 (Ottawa: Deneau Publishers, N.D.)); Glen How, Lawyer for the Witnesses (see W Kaplan, The State and Salvation, id); Peter Makaroff who represented members of the Doukhobor community and was active in left wing politics in Saskatchewan (see H McConnell, Peter G Makaroff, Q.C.: Canada’s First Doukhobor Lawyer (1992)44 Sask His 85).

The Legal Research Centre at the University of Manitoba is engaged in an ongoing project of examining the life and work of lawyers from minority ethnic groups in the province, including the Jewish, Mennonite and Icelandic communities.

35 Wes Pue, formerly head of the Canadian Legal History Project at the University of Manitoba, now holds the Chair of Legal History at the $U$ of British Columbia. See W Prue, Wrestling with Law: (Geographical) Specificity vs (Legal) Abstraction 1990) 11 Urban Geography 566.

36 For recent Canadian legal historical scholarship which draws upon feminist, 
race and ethnic history, see $\mathrm{C}$ Backhouse, Petticoats and Prejudice, supra note 9; B Ryder, Racism and the Constitution: The Constitutional Fate of British Columbian Anti-Asian Immigration Legislation, 1884-1909 (1991) 29 Osgoode Hall LJ 619; K Dubinsky \& F Iacovetta, Murder, Womenly Virtue and Motherhood: The Case of Angelina Napolitana, 1911-1922, T Loo \& L McLean eds, Law and Society in Canada, supra note 9 at 161.

There are the seeds of a legal historical literature in this area in Canada. See D Brown, The Genesis of the Canadian Criminal Code (Toronto: Osgoode Society, 1989); G Parker, The Origins of the Canadian Criminal Code, in D Flaherty ed, Essays, Vol 11, 249; M Friedland, A Century of Canadian Criminal Law: Perspectives on the Development of Criminal Law (Toronto: University of Toronto Press, 1984).

On the historical as well as the legal significance of this change, see F Vaughan, The Use of History in Canadian Constitutional Adjudication (1989-90) 12 Dalhousie LJ 59.

39 Two examples from the realm of tort law are: $R$ in the Right of Canada v. Saskatchewan Wheatpool [1983] 1 SCR 180 (rejection of statutory tort doctrine); Central Trust Co. v. Rafuse [1986] 2 SCR 147 (co-existing liability in torts and contract for negligent performance of professional services). Sir Anthony Mason, The Importance of Judicial Review of Administrative Action as a Safeguard of Individual Rights, Australian Bar Association Conference, 4 July 1994.

41 The legal and ethical implications of scholars being drawn into consulting and expert witness roles as a prelude to or within litigation are just only now being canvassed in Canada. For full and imaginative examination of this potentially thorny and sensitive problem, see H Foster \& A Grove, Looking Behind Masks: A Land Claims Discussion Paper for Researchers, Lawyers and Their Employers (1993) 27 U of British Columbia L Rev 213.

P Atiyah, The Rise and Fall of Freedom of Contract (Oxford: Oxford University Press, 1979).

43 See the texts listed at supra note 9. To be added this year is J Phillips, T Loo \& S Lewthwaite ed, Essays in the History of Canadian Law, Vol V, Criminal Justice (Toronto: Osgoode Society, 1994).

The work is being done under the auspices of the Canadian Legal History Project at the Faculty of Law, University of Manitoba by Wes Pue of UBC and Dale Gibson of the University of Alberta.

See supra note 11, and J Potter, The Liberty We Seek: Loyalist Ideology in Colonial New York and Massachusetts (Cambridge, Mass: Harvard University Press, 1983); SF Wise, Liberal Consensus or Ideological Battleground: Some Reflections in the Hartz Thesis [1974] Canadian Hist A Papers 1; P Romney, From the Rule of law to Responsible Government: Ontario Political Culture and the Roots of Canadian Statism [1989] Canadian Hist A Papers 86; R Hett, Judge Willis and the Court of King's Bench in Upper Canada (1973) 65 Ontario Hist 19.

Upper Canada was carved out of the western reaches of Quebec to accommodate English speaking settlers (many of them American Loyalists) anxious to live under English law. The Colony of Vancouver's Island was set up in 1849 to establish a formal presence on the west coast of what is now Canada. It represented colonialism on the cheap, as the colony was effectively Hudson Bay Company run. The mainland Colony of British Columbia was established in 1858 as gold miners, many from the United States, poured into the territory. The British Government sought to prevent north of the Forty Ninth Parallel a repeat of what had happened in the Oregon Territory, where penetration by settlers had been translated into a vigorous and successful claim of American possession.

47 Compare Erode, Bone and Sinew and Williams, ...The Man for a New County, 
supra note 28. See also P Brode, Grand Jury Addresses of the Early Canadian Judges (1989)23 Law Soc of Upper Canada Gazette 130; H Foster, The Kamloops Outlaws and the Commissions of Assize in Nineteenth Century British Columbia in D Flaherty ed, Essays, Vol II, supra note 9 at 308; The Struggle for the Supreme Court: Law and Politics in British Columbia, 18711885 in L Knafla ed, Law and Justice in a New Land, supra note 9 at 167; White Man's Law in the Far West, University of Manitoba Canadian Legal History Project Working Paper Series, CLHP-WPS92-12.

See supra note 33.

See supra note 34

50 See R Macleod, The Northwest Mounted Police (Toronto: University of Toronto Press, 1975); S Horall, Sir John A MacDonald and the Mounted Police Force for the Northwest Territories (1972) 5 Canadian Hist Rev 179; K Walden, Visions of Order: The Canadian Mounties in Symbol and Myth (Toronto: Butterworths, 1982); D Morton, Cavalry or Police: Keeping the Peace on Two Adjacent Frontiers (1977) $12 \mathrm{~J}$ of Canadian Stud 27; C Betke, Pioneers and Police on the Canadian Prairies, 1885-1914 in R Macleod ed, Lawful Authority, supra note 9 at 98; E Morgan, The North West Mounted Police: Internal Problems and Public Criticism, 1874-1883 (1973) 26 Sask His 41; D McLeod, Liquor Control in the North West Territories: The Permit System, 1870-1891 (1963)16 Sask His 81; T Stone, The Mounties as Vigilantes: Perceptions of Community and the Transformation of Law in the Yukon, 1885-1897 in T Loo \& L McLean eds, Law and Society in Canada, supra note 9 at 111.

N Rogers, Serving Toronto the Good: The Development of the City Police Force, 1834-1880 in V Russell ed, Forging a Consensus: Historical Essays on Toronto (Toronto: University of Toronto Press, 1991) at 116; G Marquis, Policing Canada's Century, A History of the Canadian Association of Chiefs of Police (Toronto: Osgoode Society, 1993); The Contours of Urban Justice, 1830-1875 (1987) 15 Urb Hist Rev 269; The History of Policing in the Maritime Provinces: Themes and Prospects (1990) 19 Urb Hist Rev at 84. For seminal work on the British system, see D Hay \& F Snyder, Using the Criminal Law, 1750-1850: Policing, Prosecution and the State in D Hay \& F Snyder eds, Policing and Prosecution in Britain 1750-1850 (Oxford: Clarendon Press, 1989), 3.

52 See eg D Hay, Property, Authority and the Criminal Law in D Hay et al, ed, Albion's Fatal Tree, 17; The Meaning of the Criminal Law in Quebec in L Knafla ed, Crime and Criminal Justice in Europe and Canada (Waterloo: Sir Wilfred Laurier University Press), 77; J Beattie, Attitudes Towards Crime and Punishment in Upper Canada, 1830-1850 (Toronto: Centre for Criminology, 1977); J Weaver, Crime, Public Order and Repression: The Gore District in Upheaval, 1832-1851 in R Macleod ed, Lawful Authority, supra note 9 at 22; C Backhouse, Petticoats and Prejudice, supra note 9; J Phillips, Poverty, Unemployment and the Administration of Criminal Justice in P Girard \& J Phillips eds, Essays, Vol III, supra note 9 at 128; J Price, 'Raised in Rockhead. Died in the Poor House': Female Petty Criminals in Halifax, 1864-1890 in Girard \& Phillips eds, Essays, Vol III, 200: N Boyd, The Origins of Canadian Narcotics Legislation: The Process of Criminalization in Historical Context in $\mathrm{R}$ Macleod ed, Lawful Authority, supra note 9 at 192.

53 See eg $\mathrm{H}$ Nelles, The Politics of Development: Forest, Mines and HydroElectric Power in Ontario, 1849-1941 (Toronto: University of Toronto Press, 1974); R Risk, The Law and the Economy in Nineteenth Century Ontario in D Flaherty ed, Essays, Vol I, supra note 9 at 88; The Nine nineteenth Century Foundations of the Business corporation in Ontario (1973)26 $U$ of Toronto LJ 307; The Golden Age: The Law About the Market in Nineteenth Century Ontario (1976) 26 U of Toronto LJ 307; The Last Golden Age: Property and the Allocation of Losses in Ontario in the Nineteenth Century (1977) $27 U$ of Toronto LJ 199; P George \& P Sworden, The Courts and the Development of 
Trade in Upper Canada, 1830-1860 (1986)60 Business Hist Rev 258; J Benidickson, Private Rights and Public Purposes in the Lakes, Rivers and Streams of Ontario 1860-1930 in D Flaherty ed, Essays, Vol II, supra note 9 at 365.

54 J McLaren, Nuisance Law and the Industrial Revolution - Some Lessons from Social History (1983)3 Oxford J of Legal St 155; AWB Simpson, Legal Liability for Bursting Reservoirs: The Historical Context of Rylands v. Fletcher (1984)13 1 of Legal St 209; J Nedelsky, Judicial Conservatism in an Age of Innovation: Comparative Perspectives on Canadian Nuisance Law 1880-1930 in D Flaherty ed, Essays Vol I, supra note 9 at 281; D Dewees \& M Halewood, The Efficiency of the Common Law: Sulphur Dioxide Emissions in Sudbury (1992) 42 U of Toronto LJ 1.

55 J McLaren, The Tribulations of Antoine Ratte A Case Study of the Environmental Regulation of the Canadian Lumbering Industry in the Nineteenth Century (1984)33 University of New Brunswick LJ 203.

56 G Kealey ed, Canada Investigates Industrialism (Toronto: University of Toronto Press, 1973); R Risk, 'This Nuisance of Litigation': The Origin of Workers Compensation in Ontario in D Flaherty, Essays Vol II, supra note 9 at 418; E Tucker, Administering Danger in the Workplace: The Law and Politics of Occupational Health and Safety Regulation in Ontario 1850-1914 (Toronto: University of Toronto Press, 1992).

57 See R Kostal, Legal Justice, Social Justice: An Incursion into the Social History of Work Related Accident Law in Ontario 1860-86 (1988)6 Law and Hist Rev 1.

58 P Ward, White Canada Former: Public Attitudes and Public Policy Towards Orientals in British Columbia, 2d ed. (Montreal/Kingston: McGill-Queens Press, 1990); P Roy, A White Man's Province (Vancouver: U of British Columbia Press, 1990); H Johnston, The Voyage of the Komagatu Mani: the Sikh Challenge to Canada's Colour Bar (Vancouver: U of British Columbia Press, 1989).

59 J McLaren, The Early British Columbia Supreme Court and the 'Chinese Question': Echoes of the Rule of law in Gibson \& Pue eds, Glimpses of Canadian Legal History, supra note 9 at 111.

60 R Huttenback, Racism and Empire: White Settlers and Colored Immigrants in the British Self-Governing Colonies (Ithaca NY: Cornell University Press, 1976); C Price, The Great White Walls Go Up: Restrictive Immigration in North America and Australasia 1836-1888 (Canberra: Australian National University Press, 1974); A Markus, Fear and Hatred: Purifying Australia and California (Sydney: Hale \& Iremonger, 1979); J McLaren, The Burdens of Empire and the Legalization of White Supremacy in Canada, 1860-1910 in Gordon \& Fergus, Legal History in the Making, 187. See also K Cronin, Colonial Casualties: The Chinese in Victoria (Melbourne: University of Melbourne Press, 1982); R Evans, K Saunders \& K Cronin, Racism in Colonial Queensland, 2d ed. (Brisbane: Queensland University Press, 1993).

61 J McLaren, The Early British Columbia Judges and the 'Chinese Question': The California and Oregon Connection in McLaren, Foster \& Orloff eds, Law for the Elephant, supra note 9 at 237.

C Backhouse, Shifting Patterns in Nineteenth-Century Canadian Custody Law in Flaherty ed, Essays, Vol I, supra note 9 at 212; Nineteenth Century Rape Law, 1800-1892 in Flaherty ed, Essays, Vol II, supra note 9 at 200; Involuntary Motherhood: Abortion. Birth Control and the Law in Nineteenth Century Canada (1983)3 Windsor Yearbook of Access to Justice 61; Desperate Women and Compassionate Courts: Infanticide in Nineteenth Century Canada (1984) 34 $U$ of Toronto $L J$ 447; To Open Way for Others of my Sex: Clara Martin's Career as Canada's First Woman Lawyer (1985) l Canadian J of Women and the Law 1; Pure Patriarchy: Nineteenth Century Canadian Marriage (1986)14 McGill LJ 265; Married Women's Property in Nineteenth Century Canada 
(1988) 6 Law and Hist Rev 211.

63 G Parker, The Legal Regulation of Sexual Activity and the Protection of Females (1983) 21 Osgoode Hall LJ 187; C Backhouse, Nineteenth Century Canadian Prostitution Law (1985) 18 Social History 387; D Nilson, 'The Social Evil': Prostitution in Vancouver, 1900-1920 in B Latham \& C Less, eds, In Her Own Right (Victoria BC: Camosun College) at 205; L Rotenberg, The Wayward Worker: Toronto's Prostitute at the Turn of the Century in J Acton et al, ed, Women at Work (Toronto: Canadian Women's Education Press, 1974)33; E Langdon, Female Crime in Calgary: 1914-1941 in L Knafla ed, Law and Justice in a New Land, 293; J McLaren, 'White Slavers': The Reform of Canada's Prostitution Laws and Patterns of Enforcement, 1900-1920 (1987) 8 Crim Just Hist 53; S Buckley \& J Dickin McGinnis, Venereal Disease and Health Reform in Canada (1983) 63 Canadian Hist Rev, 337; M Valverde, The Age of Soap, Light and Water: Moral Reform in English Canada, 1885-1925 (Toronto: McClelland \& Stewart, 1991); J Fingard, The Dark Side of Life in Victorian Halifax (Halifax: Pottersfield Press, 1989).

See E Bristow, Vice and Vigilance: Purity Movements in Britain since 1700 (Dublin: Gill \& MacMillan, 1977); J Walkowitz, Prostitution and Victorian Society: Women, Class and the State (Cambridge: Cambridge University Press, 1980); B Miel Hobson, Uneasy Virtue: The Politics of Prostitution and the American Reform Tradition (New York: Basic Books, 1987); M Connelly, The Response to Prostitution in the Progressive Era (Chapel Hill, N.C.: University of North Carolina Press, 1980); R Rosen, The Lost Sisterhood: Prostitution in America 1900-1918 (Baltimore: Johns Hopkins University Press, 1982); K Daniels ed, So Much Hard Work: Women and Prostitution in Australian History (Sydney: Fontana, 1984).

65 See G Marquis, Law, Society and History: Whose Frontier? (1992) 21 Acadiensis 162.

66 By way of example, through the efforts of Drs De Lloyd Guth of the University of Manitoba and Louis Knafla of the University of Calgary, access to the legal records of western Canadian provinces has been vastly improved. Knafla previously headed up the Alberta Legal History Project which was a pioneer initiative in this field.

67 See eg R.Smandych, C Matthew \& S Cox, Canadian Criminal Justice History: An Annotated Bibliography (Toronto: University of Toronto Press, 1987); J Dicken McGinnis, Bibliography of the Legal History of Western Canada in L Knafla ed, Law and Justice in a New Land, supra note 9 at 333.

68 See H Foster, Common Law for Common Folk, 2d ed (Saskatoon: Public Legal Education of Saskatchewan, 1986).

69 The Battle of Windsor, in fact an ill-planned raid by Canadians and some Americans across the Detroit River, has Australian resonances, as a group of the rebels from that conflict was charged and convicted of treason and transported to Van Dieman's Land. See G Rude, Protest and Punishment: The Story of Social and Political Prisoners Transported to Australia, 1788-1868 (Oxford: Clarendon Press, 1978).

70 I was fortunate, while at the Justice and Police Museum in Sydney, to sit in on a presentation of the Trial of Ned Kelly by students at the Sydney Boys and Newton High Schools for visiting schools. The museum was also featuring a very informative and balanced exhibit of the bushranger era and the police response to it.

71 A Castles, Australian Legal History, supra note 17; A Castles \& M Harris, Lawyers and Wayward Whigs: Government and Law in South Australia (Adelaide: Wakefield Press, 1987); D Neal, The Rule of Law in a Penal Colony, supra note 17; B Kercher, Commerce and the Development of Contract Law in New South Wales (1991) 9 Law and Hist Rev 269; The Making and Breaking of Law in Australia (forthcoming from Allen \& Unwin). 